\title{
Myth and Exegesis in Plotinus: How to Divide and Recompose Words and Things
}

\author{
José María Zamora Calvo \\ Autonomous University of Madrid, Spain. Email: jm.zamora@uam.es. ORCID ID: oooo- \\ 0001-7101-2234
}

Received May 25, 2017; Revised July 15, 2017; Accepted July 17, 2017; Published August 09, 2017.

\begin{abstract}
This paper explores the central thesis of the myth presented by Plotinus in his treatise On Love (III, 5 [50] 9, 24-29). Myth is a narrative that divides and deploys over time structures differentiated only by their "rank" or "powers". First, the myth teaches, and then allows those who have understood it to "recompose" the data scattered through the discourse. The Hesiodic genealogy -Uranus, Kronos, Zeus- corresponds to the three main hypostases -the One, the Intelligence and the Soul. Likewise, the death and later dismemberment of child Dionysus symbolize the multiplicity and impassivity of sensible matter.
\end{abstract}

Keywords: myth; Plotinus; exegesis; Neoplatonism; Dionysus

\section{Introduction}

Plotinus (204/5 - 270 C.E.) is considered first and foremost as an exegete of Plato who introduced profound changes into Platonism, in an age when "novelty" was not valued per se. As Dodds (1960, p. 2) remarks, the essence of Plotinus' system stems more from the new sense transmitted by the whole to the parts, than in the parts considered separately one from another. However, according to Plotinus, if the truth was discovered long ago, and is deposited in the Hellenic tradition, especially under the authority of Plato's dialogues, it has still to be clarified, as it was not always

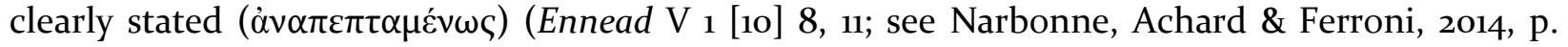
xcii). This hermeneutic method is applied especially to the philosophy of the myth.

Our intention here is to analyse the treatment of the myth in Plotinus, as the intermediary in the exegesis of his particular philosophical system, with a view to demonstrating the originality of his conception. In effect, Plotinus returns to the kinship and genealogical relationships between the elements of the myth, which explain his more traditional view, and also explores other links more deeply, such as hierarchical structure (in the myth of Zeus), or the likeness between the model and the image (in the myth of the mirror and the child Dionysus). These are all used to render more intelligible a philosophical truth which transcends the myth as such.

\section{Definition of myth: Plotinus and tradition}

In the treatise 50 On Love (III, 5), Plotinus defines myth as what takes apart and separates in time things which are simultaneous, i.e. what presents through successive generations that which in

(C) AesthetixMS 2016. This Open Access article is published under a Creative Commons Attribution Non-Commercial 4.0 International License (http://creativecommons.org/licenses/by-nc/4.0/), which permits non-commercial re-use, distribution, and reproduction in any medium, provided the original work is properly cited. For citation use the DOI. For commercial re-use, please contact editor@rupkatha.com. 
fact is ungenerated and eternal (see Pépin, 1955, pp. 5-7; 1976, pp. 190-192; Arnou, 1967, pp. 296300; Buffière, 1973, pp. 531-535; Cilento, 196o, pp. 243-311; Ramos Jurado, 1990, pp. 76-77; Saffrey, 1992, pp. 62-63; Dillon, 2004, xxviii-xxix; Oliveira, 2013, pp. 107-109; Kalligas, 2014, pp. 531-533).

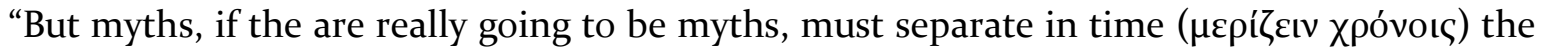
things of which they tell, and set apart ( together, but distinct in rank or powers, at points where rational discussions (oi $\lambda$ ópoı), also

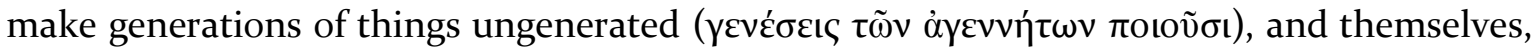
too, separate things which are together; the myths, when they have taught us as well as they

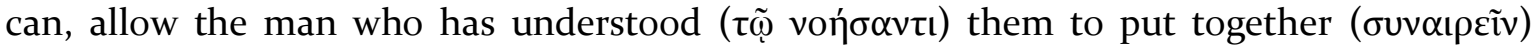
again that which the have separated." (Plotinus, Enn. III, 5 [50] 9, 24-29; trans. Armstrong, 1966-1988, vol. 3, p. 201).

The myths have a particular way of teaching us, and that peculiarity brings them closer to the dialectic method. Thus, they divide what is unified, disperse over time what is simultaneous, explain through a succession of generations what in fact is ungenerated (see Pépin, 1955, p. 7; Brisson, 2004, p. 75). The temporal diairesis of myth separates the different facets of beings, imitating to some extent the intelligible structures, which although they are together, are only different "in rank or powers".

Thus, we can distinguish two moments in the myth: (1) that of division or diairesis, and (2) that of recomposition or synairesis, which we can relate to the two moments of the dialectic method: (1) that of analysis, and (2) that of synthesis, just as Plato explains them in the various dialogues (see, e.g., Sophist, 253c; Philebus, 17a; Republic, 533c and 534e). Through the diairesis method Plato attempts to follow the natural articulations of things, just as a good butcher would do (Phaedrus, 265e1-3). Plato applies this method to the search for definitions of the sophist and the politician in the respective dialogues. Those who are able to divide and unite, as Plato tells us in the Phaedrus (366 b), he calls dialectics.

Returning to Plotinus, the diairesis carried out by the myths, which temporarily breaks down beings that in fact are compact, acts as an analytical tool that facilitates understanding, Nevertheless, once the myth has been disassembled, "the man who has understood ( $\tau \tilde{\omega}$ voń $\sigma \alpha v \tau \iota)$ "

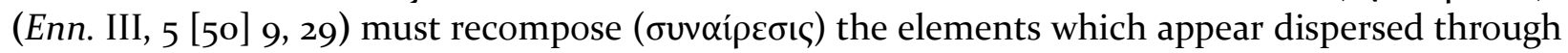
the narrative. In synairesis it is therefore necessary to move from the chronological to the hierarchical, to be able to distribute each being according to its "rank" or "powers".

\section{The fragmentation of the myth in the mirror}

Pépin (1955, p. $7 ; 1976$, p. 192) recognises the analytical and didactic value of the myth in the Enneads and connects it to Plotinus' theory of the image. Just as an object is reflected in a mirror, the image always participates in its model. In the first book of Problems concerning the Soul (Enn. IV, 3 [27] 11), Plotinus approaches the subject of how the souls accept the gods which, in this case, represent the intelligible beings. He starts by alluding to the primitive belief in "natural" sympathy, also found in theurgy, between the model and the image. The wise men among the ancients built sanctuaries and statues to ensure the presence of the gods, and they realised that the nature of the soul is easily attracted if an object is made to serve as a receptacle for some of its parts. Accordingly, what is made in imitation of something is "like a mirror able to catch [the

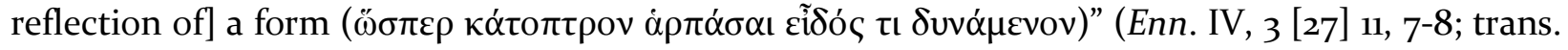
Armstrong, 1966-1988, vol. 4, p. 71). However, as the myth is simply an image, it is a reflection of reality, without being reality itself, and so the myth must be superseded, to reach the 
contemplation of the first principle.

What we find here, in the opinion of Mattéi (1996, p. 14), is "a very traditional conception of the myth", which we can relate to Aristotle's analysis of the myth in the Poetics, where he defines it as "a composition of actions ( $\sigma u ́ v \theta \varepsilon \sigma ı \varsigma ~ \tau \tilde{\omega} v \pi \rho \alpha \gamma \mu \alpha \dot{\tau} \tau \omega v)$ " (1450a3-4). Whoever listens to a mythical narrative, or reads it carefully, must rearrange the fragments into a single whole, which means establishing a connection between the visible and the invisible. This is why in fact there is no break between myth and logos, but instead there is continuity, to the point where we can consider them as branches of the same tree. The original meaning of the verb $\lambda \dot{\gamma} \gamma \varepsilon \mathrm{v}$ is "pick", or "select", which then became "collect", "bring together", "join together ", and then "speak", "say": words are "collected " or "joined together" which is what happens when we read, and so the "sense" or "meaning" is obtained (see Heidegger, 1927/1993, pp. 32-34). Thus, the myth is located midway between the visible and the invisible, "a $\mu \varepsilon \tau \alpha \xi \dot{v}$ which reflects the countenance of the intelligible in the mirror of time” (Mattéi, 1996, p. 16).

But the myth, which reflects like a mirror, makes what is immobile move, engenders what is ungenerated, i.e., it puts the intelligible structure into motion to facilitate its understanding. According to Couloubaritsis (1990a, pp. 85-89; 199ob, pp. 329-332), the myth presents a "genealogical schema", it follows the common thread of the universal schema of kinship. In the mirror of the myth, the united and compact is fragmented into successive sequences, the eternal unfolds in time, the ungenerated becomes generated. Through the table of kinship, what transcends all generation is composed genealogically, whether it refers to cosmogony, theogony or anthropogony.

In fact, the genealogical form is the most used by the archaic myth, applying the family tree, one of the most familiar standard patterns of human experience. Couloubaritsis (2008, pp. 8o-89) considers that this family pattern was used systematically because the phenomenon of kinship represented a well-organized everyday experience in archaic societies, where the ancestor cult supposed the presence of the dead in an invisible setting. Thus, extending the family tree to other areas of real life gave the language a form of expression enabling the knowledge of things to come. This extension of the family tree means that genealogy can explain a reality which is both visible and invisible, and which divides and separates in time what it attempts to convey, referring it back to an origin.

From this viewpoint, we discover the presence of genealogy permeating Greek thought from its origins to Neoplatonism, allowing us to question the common thesis of a transition from myth to logos, widely accepted since Nestle (1940). To speak of myth, then, implies a certain type of reflective activity, i.e., a certain type of logos; while at the same time, to speak of logos implies a certain form of myth.

\section{The genealogy of Plotinus: Uranus-Kronos-Zeus}

In Plotinus, the three great gods of Hesiod's theogony - Uranus, Kronos and Zeus - correspond to the three main hypostases: The One, the Intellect and the Soul. In this case, however, the relationship between these three hypostases is hierarchical, not genealogical, since each has a "rank" and a specific "power" which differentiates it from the others (see Zamora Calvo, 2012). This is similar to the relationship established in Plato's Republic between the Good and the sun. Using the genealogical relationship of kinship, the sun is said to be the son of the Good (diairesis), but the sun is ungenerated, which when recomposed means a hierarchical structure (synairesis) in which the invisible Good occupies a higher rank and power than the visible sun (see 
Couloubaritsis, 1984). From the family tree and genealogical logic, which we find at the point of diairesis in the myth, we move on to a structure which is not genealogical, but hierarchical. However, we see that through the analysis of the myth we can use the genealogical to reach an understanding of the ungenerated and invisible, by means of the visible and the generated.

The hierarchical structure of the three hypostatic natures - One-Intellect-Soul - is inspired by a particular exegesis of the Parmenides, of the Second Letter of Plato and of Numenius (see Narbonne, Achard \& Ferroni, 2014, p. xciii). Plotinus proposes an integral dynamic procession from the first principle, without this being diminished in any way. He conceives of this procession as a natural, spontaneous overabundance of power and life, which is different from the traditional cosmogonic myths and from Judaeo-Christian creationism or the technical-craftsmanship production pattern of the demiurge. The realities generate themselves eternally one from the other, they are subordinated to others and all have their source from which they proceed in the One, the absolutely simple first principle and the infinite power of all things (see Narbonne, Achard \& Ferroni, 2014, pp. lxii-lxiv, lxvi, lxxiii).

In the Enneads the same mythical character is used by Plotinus to denote various philosophical notions; inversely, a philosophical notion may have various mythical representations, although without establishing an exact correspondence - term for term between the mythical, oblique discourse and the direct discourse (see Pépin, 1958, pp. 480-481). Using the character Penia (Poverty), taken from Plato's Symposium, Plotinus denotes the matter of the intelligible world, although not only that, as the characteristics of penury taken to the extreme are also used to represent the matter of the sensible world. On the other hand, Porus (Resource), personified as the father of Eros, the garden of Zeus and the nectar, are three mythical manifestations of the logos. Inversely, the character of Zeus is not reserved exclusively to symbolize the Soul. In the interpretation of the myth of the birth of Eros, Zeus denotes Intellect, and in the treatise ${ }_{31}$ On Intelligible Beauty $(\mathrm{V}, 8)$, is associated with Dike (Enn. V, 8 [31] 4, 40-42); but is also used to represent the One or the Good (Enn. VI, 9 [9] 7, 21-26). Thus, the same mythical character, used in different contexts, allows Plotinus to make different interpretations: Zeus can represent the world soul but also each one of the three hypostases.

\section{The myth of the dismemberment of Dionysus, symbol of the sensible matter}

For Vernant (1989, p. 158), the Neoplatonists used the motif of the mirror of Dionysus to translate on the cosmological plane the change from the one to the many. In his Enneads, Plotinus makes just one single, clear reference to the myth of the death at the hands of the Titans and later rebirth of Dionysus, highlighting the mirror which distracts the child (see Pépin, 1970, pp. 315-320; Ghidini-Tortorelli, 1975; Letocha, 1978; Oliveira, 2013, pp. 277-294):

"But the souls of men see their images as if in the mirror of Dionysus (oiov $\Delta$ tovúrov $\dot{\varepsilon} v$ $\kappa \alpha \tau$ ó $\tau \rho \omega)$ and come to be on that level with a leap from above: but even these are not cut off from their own principle and from intellect." (En. IV, 3 [27] 12, 1-4; trans. Armstrong, 1966-1988, vol. 4, p. 73).

To discover Plotinus' exegesis of this myth, we must start from the relationship established between model and image within a hierarchical framework: the weakest powers proceed from previous powers, as occurs with images of objects reflected in water, in a mirror or in a shadow (see Enn. VI, 4 [22] 10, 12-17). In this case, as in others, Plotinus starts from an exegesis of Plato, especially in the Republic, where the hierarchy of the different orders of reality is shown in the relationship which exists between the model and the image: the intermediate level is the image of 
a higher level which, in turn is the model of a lower level. In the analogy of the line, Plato uses "images", first for shadows, then for reflections in water and in all things which are "close-packed, smooth, and shiny materials" (Republic, 510a2).

The meaning of the mirror is always ambivalent: (1) the mirror is the symbol of certainty and knowledge; and (2) it is the symbol of falsehood, as it only shows the outward appearance of things (see Baltrušaitis, 1978, p. 86). The symbolism of the mirror is linked to the myth of Narcissus reflected in the water, where the world, according to Cirlot (1997, p. 200), is "a huge Narcissus who sees itself reflected in the human conscience". Plotinus uses the image of the

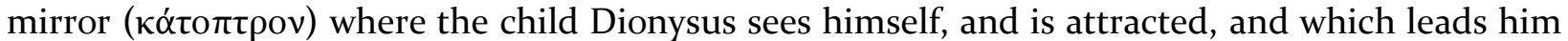
to reject the rest of the playthings his murderers the Titans offer him - which already existed in earlier writers -, but which he adapts to the requirements of his own henological and processional schema. According to Ferwerda (1965, p. 23), it is difficult to find another philosopher in the history of philosophy who compares with Plotinus in the use of this image.

But the originality of Plotinus lies in the constant comparison he makes between sensible

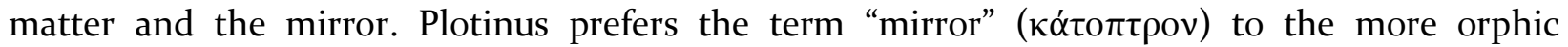

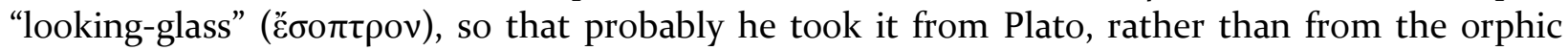
texts. The mirror is "a pathetic image, the metaphor of a cosmic, human situation" (Ghidini Tortorelli, 1975, p. 359). Many texts simply point out the analogy, substituting the mirror for the surface of the water (see Enn. II, 3 [52] 15, 5; VI, 5 [23] 8, 16-17); but in the treatise 26 On the Impassivity of the Unembodied (III, 6) the comparison appears clearer.

"Whatever announcement it makes, therefore, is a lie, and if it appears great, if is small, if more, it is less; its apparent being is not real, but a sort of fleeting frivolity (oĩov $\pi \alpha$ ípviov $\phi \varepsilon \tilde{v}$ yov); hence the things which seem to come to be in it are frivolities ( $\pi \alpha$ í $\gamma v \alpha)$, nothing

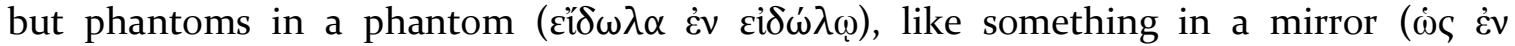
$\kappa \alpha \tau o ́ \pi \tau \rho \omega)$ which really exists in one place but is reflected in another; it seems to be filled,

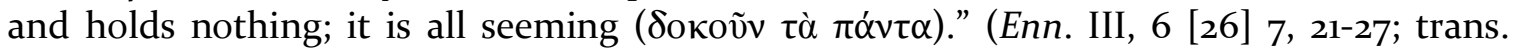
Armstrong, 1966-1988, vol. 3, pp. 241-242).?

With mirrors and transparent surfaces, the matter is not affected by the images reflected in them. But as Plotinus says, the matter is "still less liable to affections than are mirrors ("̈ $\tau$ ।

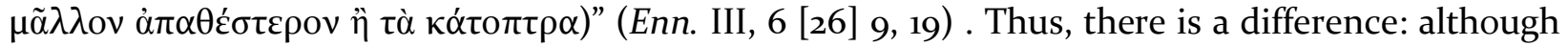
the images in a mirror, or those reflected in matter, disappear at the same time as the beings which cause them, the mirror itself can still be seen, because it is a form; but whether or not there is any content, the matter itself is not seen, because it is not a form. This is why sensible things which can be seen in matter are thought to be true, but this is not the case when they are seen reflected in a mirror (see Enn. III, 6 [26] 13, 34-46).

Thus, there would be no sensible things without matter, just as there would be no image without the mirror (see Enn. III, 6 [26] 14, 1-2). What appears in the mirror of the matter is the reflection, without reality, of the intelligible forms. The soul, both universal and particular, emits images because it appears to be present in bodies, enlightening them and converting them into animals, without entering itself into the composition of the body (see Enn. III, 6 [26] 14, 2-4).

Plotinus states that the sensible matter is impassible and incorporeal, but "otherwise" than the intelligible form, as the "substrate of bodies" and genetically previous to them (see Enn. III, 6 [26] 6, 3-7). From this, two consequences can be extracted: (1) matter is not "passible" and "versatile", as the stoics maintain (see SVF II, 482; 309), but impassible, like a mirror, or even more so; and (2) matter is incorporeal, and the body is genetically subsequent to it. The 
compound of matter and corporality is a body. Thus, both matter and the intelligible being are incorporeal; but matter is a non-being in the sense that it is different from both the sensible and the intelligible being - as it is not soul, nor intellect, nor form, nor logos, nor body, that is to say, composed of matter and form -.

Matter lacks all qualities, it is an "all-receptive" substrate of images, which remains unalterable, without undergoing any modification whatsoever, and is imperishable (see Enn. III, 6 [26] 10, 9-13; see also Plato, Timaeus, 51a7). Here, Plotinus cites the Timaeus (50c4-5): "Imitations

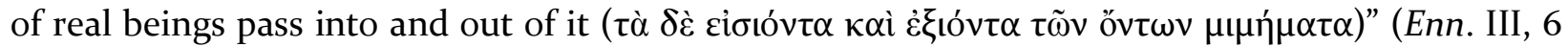
[26] 7, 27-28, and 11, 2-3). Matter, although it receives all forms, is not affected by any of them (see Enn. III, 6 [26] 11, 43-45). The substrate does not undergo any type of affection or alteration, as it lacks figure and magnitude. In matter, there is an apparent presence of images, but in reality, they are absent. Therefore, Plotinus warns, we should not allow ourselves to be swept along by routine and think that matter is passible.

Matter constantly "shuns" forms because of its own nature which is impassible (see Enn. III, 6 [26] 13, 1-2; see also Plato, Timaeus, 49e2, and 5ob-e). As matter does not emerge from itself it must be "void of all forms", and have fled from the essence of beings, so that it is not receptive of them, nor participates in their image, nor appropriates it since, if it were to lay claim to it in some way, it would instantly stop being void or "other", and the "receptacle" of all things (see Enn. III, 6 [26] 13, 20-31). Thus, when the forms pass into it and out again, it remains completely impassible, and what enters does so without leaving any trace, as a "phantasm", like an image within another image, "untrue into the untrue" (Enn. III, 6 [26] 13, 31-32).

If matter is considered as subject to affection, then it must be admitted that it is also a body, with quality and magnitude. However, matter which is neither body or magnitude, is impassible (see Enn. III, 6 [26] 12). Therefore, the images enter into it falsely, as the images of objects are reflected in a mirror while they are in front of it, but if the objects are withdrawn they immediately disappear.

The objects Hera offers to the infant Dionysus to attract his attention include a mirror made by Hephaestus, and in fact, when the Titans kill him, the child is absorbed in his image reflected in the mirror. In Plotinus, the image of the mirror constantly appears associated with matter (see Heinemann, 1926; Pépin, 1970, p. 317). In several passages in the Enneads only the analogy is indicated, with the substitution of the surface of water for the mirror, enabling us to make a hermeneutic connection between the myth of the child Dionysus and that of the adolescent Narcissus, who drowns, attracted by his own reflection (Enn. I, 6 [1] 8, 6-12; see Hadot, 1976, pp. 99-103; Brisson, 2004, p. 81).

Plotinus' interpretation of the death and dismemberment of Dionysus is metaphysical and at the same time anthropological (see Pépin, 1970, p. 317). The image ( $\varepsilon \hat{i}^{\prime} \delta \omega \lambda \mathrm{ov}$ ) of itself which the soul sees in the mirror is the reflection which descends when it is united with the body, while the soul itself remains in the higher world. Plotinus uses the myth of Dionysus dismembered to symbolize sensible matter, just as Penia refers to intelligible matter, and Narcissus, the soul trapped by his own image, refers to the sensible world.

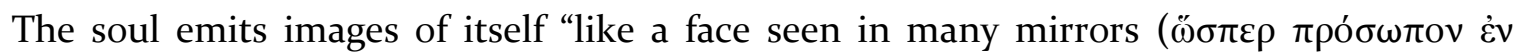

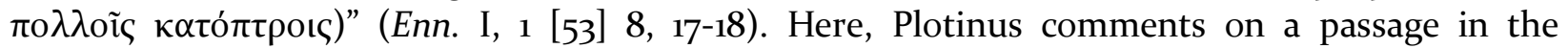
Timaeus (35a), cited above $(8,10-14)$, which refers to the composition of the world soul from the indivisible and the divisible substance. In this comparison, the mirror Plotinus is thinking of is that of Dionysus. From then on, the Neoplatonist followers of Plotinus comment on this passage 
from the Timaeus with the help of the story of the dismemberment. The myth of the child Dionysus is the symbol of the procession of the Soul from the lower level to reach matter, its final link (see Enn. IV, 8 [6] 6, 18-23). Dionysus, as Proclus says later in his Commentary on the Timaeus of Plato: "When he looked into it and saw his own image ( $\varepsilon$ " $\delta \omega \lambda$ ov $\dot{\varepsilon} \alpha \cup \tau o \tilde{v})$, he proceeded to the

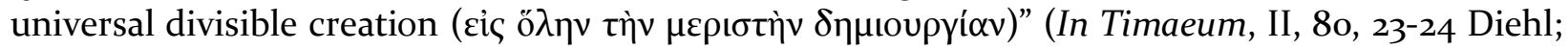
trans. Baltzly, 2007, p. 140).

\section{Conclusion}

In the Enneads, therefore, we discover a whole philosophy of the myth, which is very useful to clarify certain philosophical concepts. The myth divides in time what is transmitted in the discourse and separates entities from each other which in reality are united, meaning that the myth takes back to the past - from an origin - things which are in the present. Thus, the different births described in succession in the theogonic myths are not necessarily to be understood literally, as if they were real births, but rather as a way of explaining ungenerated and eternal things in a genealogical and temporal discourse. In the same way, the death of the child Dionysus at the hands of the Titans, when he was distracted and playing with a mirror, enables us to understand the characteristics of impassibility, multiplicity and dispersion, typical of matter in the sensible world. And the Narcissus myth, as Plotinus interprets it, represents the soul which falls in love with its own reflection, the sensible world.

The myths instruct us in their own way, but in the opinion of Plotinus, it is essential to correct their vision, as to some extent it deforms reality, since the mythical discourse divides what is one and deploys a reality which is synchronic or which transcends time. After reading or listening to the diairesis of reality carried out by the myth, it has to be recomposed (synairesis), and the primitive composition reconstructed, to achieve a full understanding of the mythical discourse. Thus, the myth provides a very useful tool for philosophical analysis, precisely because it divides a simultaneous reality in time. It is an easy form of expression, since it is based on the commonest and best known data of human experience, such as kinship, or the image reflected in a mirror, and it can be used to translate the most difficult points of philosophical expression, as in the case of the ineffable realities, the characteristics of matter and the genesis of the sensible world. For the Neoplatonists it was essential to use the mythical, oblique expression, to attain an understanding of concepts where more direct language finds itself in difficult terrain.

\section{Acknowledgement}

This paper is part of the R \& D Project (Ref. H2015/HUM-3362), "Actividades de Investigación Social en Mitocrítica Cultural (Acis\&Galatea)", supported by the Directorate General of Universities and Research of the Community of Madrid (Spain), and the activities of the UAM

Research Group: "Influences of Greek Ethics on Contemporary Philosophy" (Ref. F-055). The author would like to thank especially Lambros Couloubaritsis and Tomás Pollán for their invaluable comments.

\section{References}

Armstrong, A. H. (1966-1982). Plotinus. Enneads, I-VII: Greek Text with English Translation and Introductions, 7 vols. Cambridge, Mass./London: Harvard University Press. 
Arnim, H. von (1903-1905). Stoicorum Veterum Fragmenta [SVF], 4 vols. Lepizig: Teubner.

Arnou, R. (1967). Le désir de Dieu dans la philosophie de Plotin. Roma: Presses de l'Université Grégorienne.

Baltrušaitis, J. (1978). Le Miroir, révélations, sciences-fiction et fallacies: essai sur une légende scientifique. Paris: A. Elma Yan.

Baltzly, D. (2007). Proclus. Commentary on Plato's Timaeus. Vol. III, Book 3, Part I: Proclus on the World's Body. Cambridge: Cambridge University Press.

Brisson, L. (2004). How Philosophers Saved Myths: Allegorical Interpretation and Classical Mythology. Chicago: University of Chicago Press.

Buffière, F. (1973). Les mythes d'Homère et la pensée grecque. Paris: Les Belles Lettres.

Burnet, J. (1900-1907). Platonis Opera, 5 vols. Oxford: Clarendon Press.

Cilento, V. (1960). Mito e poesia nelle Enneadi di Plotino. In E. R. Dodds (Ed.), Les sources de Plotin: dix exposés et discussions. Vandoeuvres-Genève: Fondation Hardt. 243-323.

Cirlot, J. E. (1997). Diccionario de símbolos. Madrid: Siruela.

Couloubaritsis, L. (1984). Le caractère mythique de l'analogie du Bien dans République VI. Diotima Athinai, 12, 71-80.

Couloubaritsis, L. (1990a). De la généalogie à la genèséologie. In J.-F. Mattéi (Ed.), La naissance de la raison en Grèce. Actes du Congrès de Nice, mai 1987. Paris: Presses universitaires de France. 83-96.

Couloubaritsis, L. (199ob). La logique du mythe et la question du non-être. Revue de théologie et de philosophie, 122(40), 323-340.

Couloubaritsis, L. (2008). La pensée de Parménide: en appendice, traduction du poème. Bruxelles: Ousia.

Diehl, E. (1903-1906). Procli Diadochi in Platonis Timaeum commentaria, 3 vols. Leipzig: Teubner.

Dillon, J. (2004). Plato's Myths in the Later Platonist Tradition. In C. Partenie (Ed.), Plato. Selected Myths. Oxford: Oxford University Press. xxvi-xxx.

Dodds, E. R. (1960). Tradition and Personal Achievement in the Philosophy of Plotinus. Journal of Roman Studies, 5o(1-2), 1-7.

Ferwerda, R. (1965). La signification des images et des métaphores dans la pensée de Plotin. Groningen: J. B. Wolters.

Ghidini-Tortorelli, M. (1975). Un mito orfico in Plotino (Enn. IV, 3 (27), 12). Parola del passato, 30, 356-36o.

Hadot, P. (1976). Le mythe de Narcisse et son interprétation par Plotin. Nouvelle revue de psychanalyse, 13, 81-108.

Heidegger, M. (1927/1993). Sein und Zeit. Tübingen: M. Niemeyer.

Heinemann, F. (1926). I. Die Spiegeltheorie der Materie als Korrelat der Logos-licht-Theorie bei Plotin. Philologus-Zeitschrift für antike Literatur und ihre Rezeption, 81(1-4), 1-17.

Henry, P. \& Schwyzer, H.-R. (1964-1982). Plotini Opera [Enn.], 3 vols. Oxford: Clarendon Press.

Kalligas, P. (2014). The Enneads of Plotinus: a Commentary. Volume 1. Princeton, NJ: Princeton University Press.

Letocha, D. (1978). Le statut de l'individualité chez Plotin ou le miroir de Dionysos. Dionysius Halifax, NS, 2, 75-91.

Mattéi, J.-F. (1996). Platon et le miroir du myhte. De l'âge d'or à l'Atlantide. Paris: Presses universitaires de France. 
89 | Myth and Exegesis in Plotinus: How to Divide and Recompose Words and Things

Narbonne, J.-M., Achard, M. \& Ferroni, L. (2014). Plotin, Euvres complètes, t. I, 1, Introduction générale, Traité 1: Sur le Beau. Paris: Les Belles Lettres.

Nestle, W. (1940). Vom Mythos zum Logos: die Selbstentfaltung des griechischen Denkens von Homer bis auf die Sophistik und Sokrates. Stuttgart: A. Kröner.

Oliveira, L. (2013). Plotino, escultor de mitos. São Paulo: Annablume Clássica.

Pépin, J. (1955). Plotin et les mythes. Revue philosophique de Louvain, 53(37), 5-27.

Pépin, J. (1970). Plotin et le miroir de Dionysos (Enn. IV, 3 [27], 12, 1-2). Revue internationale de philosophie, 24(92), 304-320.

Pépin, J. (1976). Mythe et allégorie: les origines grecques et les contestations judéo-chrétiennes. Paris: Études augustiniennes.

Ramos Jurado, E. A. (1990). Mito y filosofía en el Neoplatonismo. In A. Díaz Tejera (Ed.), Cinco lecciones sobre la cultura griega. Sevilla: Universidad de Sevilla. 71-88.

Saffrey, H.-D. (1992). The Neoplatonists and Greek Myths. In Y. Bonnefoy (Ed.), Greek and Egyptian Mythologies. Chicago: University of Chicago Press. 6o-66.

Vernant, J.-P. (1989). L'individu, la mort, l'amour: soi-même et l'autre en Grèce ancienne. Paris: Gallimard.

Zamora Calvo, J. M. (2012). Teogonía de Derveni y genealogía plotiniana. Alpha, 34, 77-93.

José María Zamora Calvo is Associate Professor of Ancient Philosophy at the Autonomous University of Madrid, Spain. Philosophy degree with honours (University of Valladolid, 1993) and PhD in Philosophy with honours (University of Valladolid, 1998). Since 2008, he is president of the Spanish Section of ISNS-International Society for Neoplatonic Studies, and coordinator of the UAM Research Group: "Influences of Greek Ethics on Contemporary Philosophy" (Ref. F-055). ORCID ID: oooo-ooo1-7101-2234. Email: jm.zamora@uam.es 